\title{
Manifestation of At-Tadayyun in Life
}

\section{Mohd Aderi Che Noh, Engku Zarihan Engku Abdul Rahman}

Faculty of Education, Universiti Kebangsaan Malaysia, Bangi, Malaysia

Email: a deri@ukm.edu.my

How to cite this paper: Noh, M. A. C., \& Rahman, E. Z. E. A. (2018). Manifestation of At-Tadayyun in Life. Creative Education, 9, 2376-2384.

https://doi.org/10.4236/ce.2018.914178

Received: August 16, 2018

Accepted: October 28, 2018

Published: October 31, 2018

Copyright (C) 2018 by authors and Scientific Research Publishing Inc. This work is licensed under the Creative Commons Attribution International License (CC BY 4.0).

http://creativecommons.org/licenses/by/4.0/

\begin{abstract}
At-Tadayyun is the most important measure of a person to see how far his confidence in the message of Islam, obedience to the commandments and determination in leaving His prohibitions. Through the thinking ability that was made by Allah to man, it's a starting point that the ability to accept, embrace and implement the teachings of Islam. At-Tadayyun derived from ad-Din, which shows the properties of social life that give a wider meaning encompassing the whole of human life. Its role is to lead towards the truth to perform live and interacts with others. With at-Tadayyun compound in a person, the primary responsibility as a servant who devoted an entire devotion to Allah and the role of Caliph inhabit the earth can be performed well as was enlightened by the Prophet Muhammad SAW during his life. Hence, this paper explores in depth the concept of at-Tadayyun in Islamic perspective and basic concepts underlying the elaborate nature of Iman, Islam and Ihsan. The manifestation of the principle of at-Tadayyun expressed true faith and worship, and noble character. As such, it fulfils the concept of at-Tadayyun and needs in human life as handed down by the Prophet Muhammad SAW.
\end{abstract}

\section{Keywords}

At-Tadayyun, Human Nature, The Message of Islam, Slaves, Caliph

\section{Introduction}

Humans are creatures of Allah SWT which consists of elements of spirit and body. This creation of human beings is glorified with the gift of reason which at the same time elevates his dignity to the best of events as mentioned in at Tin verse 4 - 6 (Basmeh, 1998). Humans are created with the power of reason to master and govern nature. Allah SWT subdued nature for human benefit including animals (Hijazi, 2005). This is in line with the nature of the human being provided by Allah SWT invites to love, help, prioritize justice and noble character. However, human beings will also be restored by Allah SWT to the base of 
the fire of hell with the worst recompense to fall into the evil valley that moves the elements of evil (Hijazi, 2005) so they reject the revealed truth, and according to the lusts that lead to damage.

Through the ability of humanity, humans can form knowledge either true or false that encourage them to do good or evil (Haron Din, 1990). Man is given the role of Allah SWT to fulfill the duty of worship by laying devotion only to Allah SWT and thus prospering this world as his caliph on earth. The execution of this responsibility should be guided by the divine treatise that forms human beings who bind themselves to the obedience of the Creator. Therefore, the understanding of the concept of At-Tadayyun based on the aspects of Faith, Islam and Ihsan can produce Muslims who have the true faith, the prosperous worship and noble character that bring happiness in the world and the hereafter.

\section{At-Tadayyun Concepts}

At-Tadayyun is the most important gauge for a person to see the extent of his firmness and belief in the value of Islamic teachings, his obedience to what Allah SWT instructs and his diligence in leaving all his prohibitions. At-Tadayyun is derived from the word ad-Din which is often used in the Qur'an, indicating the social attributes of a wider meaning encompassing the whole life including action (Aziz, 2013) which leads and demonstrates the direction of truth to man about how to implement life and interact with fellow humans. Zaidan (tt) describes at-Tadayyun as a social phenomenon which means commitment to trust, religious obligations and its implementation.

At-Tadayyun is derived from the word 'din' which is often used in the Qur'an; shows the broader social nature of life that encompasses life as a whole, including the actions that lead and show the truth to man about how to execute life and interact with fellow humans. Islam as 'din' is a complement to human life, which includes teaching that leads to peace, prosperity and happiness for the wellbeing of the world and the hereafter. This coincides with the word of Allah swt in surah al-'A'raaf verse 172 (Basmeh, 1998).

Abdul Rahman An-Nahlawi (2002) summarizes the meaning of ad-Din as a perfect Divine system that encompasses the entire system of life based on submission and servitude to Allah SWT and adheres to the teachings brought by the Prophet. While Al-Maududi (1985) examined the meaning of ad-Din as a term that covers all human affairs in the world and the hereafter includes; absolute power (al-Mukmin 40: 64-65; al-Bayyinah 98: 5); submission of inner birth and inner being accompanied by obedience and loyalty to that power (al-Anfaal 8:83; az-Zumar 39: 2-3); Faith and charity under absolute power (Yusuf 12:40; ar-Rum 30; al-Kafirun 109: 6) and rewards given in return for those who do good which proves it by submission to the prescribed rules, or groups doing evil by deviating from it (az-Zariyat 51: 5-6, al-Mau'un 107: 1-3).

In the Malaysian context, at-Tadayyun refers to the practice of a Muslim in his life either individually from the aspect of faith, worship and morals or involving 
other individuals (Ghani \& Mansor, 2006). While the concept of religious appreciation in the context of Islam is an appreciation of Islam because religiousity means Islamic (Mahmood Zuhdi, 2006). This is further reinforced by Al-Qaradhawi (1984) which illustrates the concept of religious appreciation as an expression of religion in all aspects of life with fullness based on the understanding of the creed as a living, worship as a practice of life, shariah as a rule and consideration of life, noble as a living ethic including abstaining from shirk and prohibited by Allah SWT.

The foundation of human beings capable of executing the original claim of the incident, namely as slaves and caliphs born from the understanding and appreciation of the three main elements which are the basis of which is Faith, Islam and Goodness. The essence of these three fundamental principles is explained by the Prophet (peace and blessings of Allaah be upon him) briefly and compactly in the second hadith in the set of 40 hadiths by Imam An-Nawawi relating to the arrival of Jibril to the Prophet who conveyed the meaning of Faith, Islam and Ihsan (An-Nawawi, 1984).

Iman which is an essential foundation which is the foundation of a personal believer who becomes the source of energy and the birthplace of everything needed in a human life. It is the basis of human dependence beyond the importance of life, wealth, family, race, homeland and others (Shamsul, 2012) which is explained by Allah SWT in surah Ali Imran verse 102. While the hadith narrated by Imam Muslim, quotes the Prophet's answer to the question of Sufian bin Abdullah RA which means:

O Messenger of Allah, teach me about the religion of Islam for teaching that I do not need to ask other people. The word Rasulullah SAW means: Say I believe in Allah, then istiqamah (according to the right path.)

(Shamsul, 2012)

Islam in terms of language means surrendering to Allah SWT (An-Nahlawi 2002), obedient, loyal and obedient (Semait, 1979), complete submission and obedience in accordance with the word of Allah SWT in surah Ali Imran verse 83. According to the term syara', Islam gives the purpose of upholding and following all that the Messenger of Allah (peace and blessings of Allah be upon him) said and believing all that the Prophet (peace be upon him) conveyed was true from Allah SWT (Semait, 1979). When a person believes in the fundamentals of Islamic thought that is the absolute belief in Allah SWT by sanctifying him from any affiliation and chanting, believing in angels, apostles, books, life after death, qadar, two words of syahadah, performing fardhu prayers, fasting month of Ramadhan, paying zakat, performing a pilgrimage once in life if able, abstaining from an unlawful matter; he is the Muslim believer (At-Thontowi, 1997).

While Ihsan in terms of language means doing good. However, in a wider context it gives meaning to the perfection of worship by safeguarding divine rights, maintaining it with awareness, experiencing the greatness of the worshiped God and believing in His greatness from the beginning to the end (Se- 
mait, 1979). Goodness produces the nature of muraqabah that is knowledge that Allah SWT constantly observes internal and external matters (Ibn Qayyim, t.t) (Al-Baqarah: 253; 33:52; 57:4). As a result, a Muslim who has the attribute of muraqabah has always experienced the greatness of Allah SWT in his heart, practicing with sincerity to cultivate the love of Allah SWT.

The manifestation of human attachment with the foundation of Faith, Islam and Ihsan creates a true faith, a religion of prosperity and morality which is a result of aqidah and worship. The true Aqidah comes by clearing the monotheistic thought and the divine perfection of all the pollutions that occurred to him throughout the ages, purifying prophetic thoughts and pamphlets from all the wrongdoing to it. It also cleanses the minds of the Hereafter from all the evil elements that entail such as the imagination and denunciation of the ignorant, extremist deviations and deceitful practitioners of the practice of khurafat (al-Qardhawi 2000). Aqidah tauhid is clear and clean from misleading beliefs, additions (bid'ah), superstitions and superstitions that sneak into the minds of men who are not guided by the treatise of truth (al-Baqarah verse 116).

Ibadah to Allah SWT covers the whole life that sets up all affairs starting individually and involving the development of the state from the political, economic, muamalat and punishments and principles of international relations during peace or war (Al-Qaradhawi, 2000). Islam comes with an intellectual and human system of living, determining the behavioral ethics and its relationship based on the instructions brought by Divine Manhaj. Implementation of worship is a setting of the life of a Muslim through the implementation of prayers, the arrangement of dietary patterns through fasting, socio-economic obligations through zakat and social bonds through pilgrimage (An-Nahlawi 1995). With the perfection of the thinking system conferred by Allah SWT upon mankind, ibadah in Islam is more of a righteous practice and spiritual training tied up by the essential meaning of human nature as mentioned in al-An'aam verses162 to 163.

The noble character is the basic objective of the Islamic treatise (Yakan, 1988) coincides with the purpose of the Prophet's message which means:

Verily I am not sent except to perfection of morality.

(Fathi Yakan, 1992)

Morality is the inner state of humanity that produces simple acts without the need for thought (Al-Ghazali, 1998). It is a major issue of self-esteem, family, community and country (Fathiyah, 2012). According to Stapa (1995), morality is a harmonious act in itself that does not require individuals to think for it. According to Al-Ghazali (1998), morality can be developed by forming good morals, removing bad habits and treating moral problems. Among the things proposed in this process are the exemplary methods (Alavi, 2008), advice and oversight (Ulwan, 1996).

Worship without morality is a worship that is of no value because it is only revealed by movement and act alone. The noble character is the essence of all worship because the practice of non-worship is merely customary and unproductive behavior (Yakan, 1988). 


\section{Fitrah Insan}

According to Shihab (2003), there are three terms used in the Qur'an referring to human, namely: 1) consisting of letters alif, nun, sin such as ins, nas or unas; 2) basyar; 3) The sons of Adam or the zuriyat Adam. Man is created by Allah SWT with the provision of potential that enables him to take responsibility as servant (Az-Zaariyat: 56) and the caliph on earth (Al-Baqarah: 30). Islam as ad-Din is a complement to human life, which includes teaching that leads to peace, prosperity and happiness for the well-being of the world and the hereafter. This coincides with the word of Allah SWT in surah Ar-Ruum verse 30.

Among the characteristics of human nature is the tendency of religion to accept Allah SWT as Lord (Langgulung, 1984). According to Shihab (2003), the nature is meant to be the essence of man who started the beginning, bringing the potential of religious faith (tauhid). In the context of this verse it means that religious liberty will be inherent in human beings forever, though it is likely that it is not recognized and neglected.

While interrelation between religion or ad-Din with human nature is asserted by al-Qaradawi (2001) stating that ad-Din is something that is felt by man as a natural need or insistence that acknowledges them and the nature around them to have the Great God. In accordance with the fitrah provided by Allah SWT to this man, the message of the Prophet Muhammad SAW which brings the Divine Truth as the indicator of truth is in accordance with the will and needs of man in carrying out responsibility on this earth as servant of Allah SWT and His caliphs which bring prosperity to nature.

\section{At-Tadayyun's Claims in the Human Life}

Understanding the concept of at-Tadayyun, its appreciation and implementation in human life is a special demand that needs to be a priority. It is a fundamental need related to the core of life, the secret of existence and the crucial issues that become a claim in human life.

1) Reason for Knowing the Reality of Life

In accordance with the creation of human beings who are the creatures of Allah SWT who have the ability to think, human beings are given the ability to understand things that are beyond their own. The Word of Allah SWT in surah Ali Imran verse 190.

According to Ibn Khaldun, humans have the ability to think because they have the ability of tamyiz to distinguish (Ardiansyah, 2013), In addition, there are many human potentials mentioned in the Qur'an, such as praising and honoring people with their best creation (al-Tin 95: 5) and the affirmation of his glory over most other creatures of Allah SWT (al-Isra 17:70). However, there are Qur'anic verses which denounce humans for their negligence and disbelief (Ibrahim 14:34), many argue (al-Kahfi 18:54), being complaining about allegiance (al-Ma'arij 70:19) (Shihab, 2003).

The essence of the mind which Allah has bestowed upon us requires guidance 
because of its limitations in thinking of matters beyond human ability. With the potential of intellect and other potentials that Allah Almighty has bestowed upon them, the concept of at-Tadayyun is cultivated and cultivated into a habit and inherited within itself in accordance with the character of man itself.

2) The Needs of Human Nature

Humans are creatures created by Allah SWT rather than merely human intellect, but also have feelings and spirits that form the foundation of nature and human nature. According to Al-Qaradhawi (2000), human nature is always thirsty and never satisfied with the benefits of material knowledge and pleasure until it believes in the existence of Allah SWT. Therefore, Allah SWT always reminds people that they are always cautious about the fact that the world is full of pleasure and deceit as he says in surah al-Hadid verse 20.

Therefore, Allah SWT directs the human nature to return to the original nature by referring to the true significance of the virtues and disadvantages in accordance with the limits set by Allah SWT as he says in Surah Al-Rum verse 30 . By taking the essence of the Divine Truth as a grip who guides the way in the world, the human nature will be filled and calm, far from the error returning to its true nature ie, self-sacrificing to the Creator.

3) Healthy soul and spiritual strength

Healthy soul and spiritual strength need to be fed in accordance with its nature. Strong spirit and soul lies within the complete and perfect Islamic treaties covering both the spiritual and physical need. Beliefs in the justice and affection of Allah SWT, good and bad rewards during the Day of the Judgment will bring forth healthy soul and the spiritual strength to mankind. Allah's commandment describes how important a soul and spiritual health is to guide one to the straight right path in surah al-Fajr verses 27 to 30 .

Any soul void of its spiritual needs that is able to give it strength will be filled with the desires to bring harm and destruction of human nature supplied by Allah SWT. Humans who live without strong beliefs often face mental stress, nervous tension and thought disorders, easily relentless and make mistakes in finding solutions (Al-Qaradhawi, 2000). Without the concept of at-Tadayyun within a person, he will experience a tendency towards the opposite of Allah SWT's fitrah. This is parallel to Arnold Toynbee's (Al-Qaradhawi, 2000) view of a historian and philosopher:

"Religion is a true creation and human nature. Suffice to say that the need for religion causes, for example, when a person feel discouraged, he will seek religious entertainment to deal with the things that he has not been able to deal with.

(Al-Qaradhawi, 2000: p. 6)

Therefore, only the appreciation of the concept of At-Tadayyun that serves to create spiritual and human psychology in everyday life (Arifin, 1977) is able to balance the internal and external elements, thus producing good manners and good qualities as suggested by Imam Al-Ghazali:

"And the most beneficial manners is to cultivate and understand the religion, 
zuhud in the world and makrifat (know) Allah SWT."

4) Encouragement and regulation in society

A prosperous society is a society that is always protected from the damage caused by over-the-limit actions of its members. Meanwhile, good and straight akhlaq or morals is a manifestation of a healthy soul and spirit (Al-Ghazali, 1988: p. 1053). In the context of life as a community, men always need encouragement and motivation that stimulates them to commit to their obligation and perform goodwill. At the same time, men also require discipline and regulation that monitors their behavior to always be on the right track and does not violate and neglect their responsibility towards others. This is in line with the word of Allah SWT, always reminding his servant of the responsibility towards himself and others as he says in surah at-Tahrim verse 6 .

Rasulullah SAW's hadiths is also an encouragement for mankind to always carry out their responsibilities with full trust as it means:

Every one of you is a leader and each of you is responsible for what you lead. (History of Imam Muslim)

Therefore, beliefs, confidence, appreciation and implementation of religious rules are an essential requirement in educating the soul, cleansing the morals, forming the impulse that promotes goodness as well as to avoid evil (Al-Qaradhawi, 2000). It is a guarantee to every member of the community to continue being motivated towards goodwill and in maintaining morals in every aspect. Hence, a society that is advanced and forward either spiritually or in material development that drives the growth and prosperity of a nation will be created.

5) The spirit of cooperation and silaturrahim (kinship)

Man cannot live alone. Each individual is always interested with others. Through an understanding of the underlying foundations of at-Tadayyun, the kinship based on the bond of faith will formed and achieve unity. Life as a community will not be created unless there is a co-operation among its members through rules governing the relationship ethics, determining the rights and obligations of each other (Al-Qaradhawi, 2000). The spirit of co-operation helps and benefits a community, invites its members to goodness and prevents misbehavior suggested by Allah SWT in surah al-Maa'idah verse 2 .

On the contrary, community life that stands in the interests of the individual cannot survive in the test is it internal or external. With the essence of at-Tadayyun, cooperation based on true iman (faith) will be formed which in turn leads to unity and high spirit of kinship, loving and helping each other because of Allah SWT.

\section{Conclusion}

The true concept of faith is not limited to verbal and limbs actions or just feelings. It begins with the consciousness of mind and heart with absolute confidence evidenced in the form of submission and obedience to the established rules (Al-Qaradhawi, 2000). It is evident by the concept of at-Tadayyun which 
translates to appreciating, practicing and implementing the command of Allah SWT and abandoning His entire ban in all aspects of life encompassing all of its dimensions namely aqidah, ibadah and akhlak.

The perfection of the tauhid concept which is delivered through the message of the prophets contains the essence that conformed to human nature which is also followed by Prophet Muhammad S.A.W (blessings and peace be upon him) as the last messenger to complete the ad-Din concept up to the end times. While human, with their nature and limitations of intellectual ability, always aim at the teachings that are capable of driving towards the happiness of life in the world and the hereafter. Through the underlying foundation and the dimensions of birth encompassing the whole of human life, the concept of at-Tadayyun proves its role in human life, individually or in a larger community that involves other individuals in achieving prosperity in the world as well as in the Day of Judgment.

\section{Conflicts of Interest}

The authors declare no conflicts of interest regarding the publication of this paper.

\section{References}

Alavi, H. R. (2008). Nearness to God: A Perspective on Islamic Education. Religious Education, 103, 5-21. https://doi.org/10.1080/00344080701807361

Al-Ghazali, A. H. M. M. (1998). Ihya' Ulum al-Din. Jilid 3 dan 4. Beirut: Dar Al-Kutub al-'Ilmiyyah.

Al-Maududi, A. A. (1985). Asas-Asas Islam. Terj. H.O.K. Rahmat. Kuala Lumpur: Dewan Pustaka Fajar.

Al-Qaradhawi, Y. (2000). Pengantar Pengetahuan Islam. Terj. Mohammad Zaini Yahya. Bandar Baru Bangi: As-Syabab Media.

An-Nahlawi, A. R. (1995). Pendidikan Islam; di rumah, sekolah dan masyarakat. Jakarta: Gema Insani Press.

Ardiansyah, L. (2013). Pemikiran Ibnu Khaldun Tentang Pendidikan. Tesis Sarjana, Universitas Negeri Yogyakarta.

Arifin, H. M. (1977). Psikologi dan beberapa aspek kehidupan ruhiyah manusia. Jakarta. Bulan Bintang. Pustaka Al-Husna. Indonesia.hlmn. 74.

At-Thontowi, A. (1997). Islam Yang Semestinya Difahami. Terj. Zainuddin Ismail dan Anwar Fakhri Omar. Pustaka Salam Sdn. Bhd.: Kuala Lumpur.

Aziz, A. (2013). Religiosity and Personal Values of Muslim Undergraduates in Malaysian Private University. UK: University of Wales.

Basmeh, A. (1998). Tafsir Pimpinan ar-Rahman. Kuala Lumpur: Bahagian Hal Ehwal Islam Jabatan Perdana Menteri.

Fathiyah, M. F. (2012). Peranan dan Cabaran Guru Dalam Pengajaran Pendidikan Islam. Sedang: Penerbit Universiti Putra Malaysia.

Ghani, Z. A., \& Mansor, N. S. A. (2006). Penghayatan agama sebagai asaspembangunan pelajar: Analisis terhadap beberapa pandangan Al-Imam Al-Ghazali. Rujukan dari. http://eprints.utm.my 
Haron Din, Dr. (1990). Manusia dan Islam. Jilid 3. Cetakan Pertama. Dewan Bahasa dan Pustaka: Ampang, Selangor. hlmn 338.

Hijazi, M. M. (2005). Tafsir al-Wadhih Juz 30. Terj Bahagian Terjemahan Editorial. Pustaka Salam Sdn. Bhd. Batu Caves Kuala Lumpur. Hlmn 173.

Ibn Qayyim, A.-J. (t.t). The Station of Muraqabah. Sunnahonline.com. 6 Oktober 2015.

Langgulung, H. (1984). Manusia dan Pendidikan: Suatu Analisa Psikolog dan Pendidikan.

Mahmood Zuhdi, A. M. (2006). Penghayatan Agama Sebagai Paksi MelayuGlokal. Konvensyen Melayu Glokal. Kuala Terengganu: Terengganu Devlopment Institute, hlmn. 1-5.

Semait, S. A. (1979). Kuliah Subuh 1. Singapura: Pustaka Nasional.

Shamsul, M. N. (2012). Hakikat Hidup Beriman. Yamani Angle Sdn. Bhd: Batu Caves, Selangor.

Shihab, M. Q. (2003). Wawasan Al-Quran: Tafsir Maudhu'i atas pelbagai persoalan umat. Bandung: Mizan Media Utama, ms 284.

Stapa, Z. (1995). Akhlak dan Tasawwuf. Kuala Lumpur: Berita Publishing Sdn. Bhd.

Ulwan, A. N. (1996). Tarbiyah al-Awlad fi al-Islam. Jilid 1 \& 2: Kaherah: Dar As-Salam.

Yakan, F. (1988). Apa Erti Saya Menganut Islam. Terj. Alias Othman. Kuala Lumpur: Pustaka Salam.

Zaidan, A. A. (t.t). Ilmal-Ijtimai' al-Dini. Cairo: Maktabah Gharib. hlmn. 63. 